ment last Friday morning). One consequence is that much of the general press in Britain has been trivialized. Another is that British public life continues to perpetuate the old unfashionable distinction between the insiders and the rest. Yet, blunderbuss though it may be, the government cannot rely on the Official Secrets Act in the pursuit of reasonable objectives; it suspects, probably correctly, that juries would not convict people of criminal offences under the act when the "official information" concerned does not damage national security. It has thus been compelled to prosecute its campaign against $\mathrm{Mr}$ Peter Wright, the retired British spy, under the law of confidentiality rather than prosecuting all readers of his book Spycatcher who happen to be British under the rubric of receiving unauthorized official information.

Mr Shepherd's bill, thrown out last Friday, would not have touched the question of military security, nor even swept away Section 2 of the Official Secrets Act, but would have civilized it, not least by removing the obvious ambiguities. Under the proposed rules, prosecutions would still have been possible, but the courts would have to decide on two matters - the degree of damage done to the national interest by the disclosure of information and the extent to which the public interest is, in the process, served (which would have become a defence against a prosecution). It would also have become a defence to show that the disputed information had become public knowledge (the Peter Wright book, for example). It is a sad business that it has been thrown out, not merely because it is a lost opportunity for reform but because it shows up yet another weakness of the British system - the capacity of governments with a sufficient majority to do what they like in the House of Commons.

What happens next will be at least diverting. Plainly the House of Commons has been humiliated by the government's scorn of its rights, every bit as galling as would have been an assertion by the Reagan administration that it would not have Congress discuss the recent sale of arms to Iran until it had produced its own report on the subject. That Mr Hurd did not last week explain why the government believes Mr Shepherd's bill to have been deficient, but merely asked that the government should be given more time to make up its mind, is hardly likely to induce the conciliatory spirit the government needs in the middle of a heavy and contentious legislative programme. Can this be, people elsewhere will be asking, the place that calls itself the "mother of parliaments".

The irony is that an intelligent account of the government's difficulties could have been persuasive, giving it the chance of winning the argument as well as the vote. The British government shares with others the difficulty of drawing a distinction between questions that bear directly on the national interest and questions that are merely politically sensitive. But it is also hampered by its own constitution, and by the doctrine of collective Cabinet responsibility (the government consists solely of its ministers, who are by definition always at one) and by the convention which flows from that each minister is king in his or her department, solely responsible for its acts and policies. From this it seems to many to follow that there cannot be in Britain a Freedom of Information Act along the lines of those spreading elsewhere, for the mountains of paper passing between civil servants are in principle irrelevant to political decisions.

In fits and starts over the past eight years, the present government has shown willing to acknowledge the unreality of these conventions by administrative means, encouraging the publication of material previously withheld. But it has also seriously blotted its copybook by its petty pursuit of unauthorized leaks of information, many concerned with defence and security matters, but some in which disclosure has chiefly been politically embarrassing. What last week's defeat for the Shepherd bill implies is that it will no longer be possible to look for an administrative solution, but that the Official Secrets Act will have to be reformed. Moreover, it is difficult to think that Mr Hurd can do much better than Mr Shepherd. But he will have to try.

\section{One country's shame}

Two US academies have chilling things to say about the imprisonment of scientists in Somalia.

GovernMENTS at times feel compelled to take steps that may be painful or obnoxious so as to protect some greater goal, but no country can claim a history free from acts it might now repudiate as unnecessarily harsh. But the realization that excesses will occur is no reason for condoning them, and it falls to governments where time and good fortune have provided perspective to speak out boldly when others stumble on the path.

These platitudes are prompted by the report of a delegation sponsored by the human rights committees of the National Academy of Sciences and the Institute of Medicine, which has chillingly made it clear that the government of Somalia has overstepped the bounds of acceptable behaviour in its pursuit of "national security". The delegation visited Somalia late last year, and returned with stories of torture, inhuman conditions for prisoners and a legal system that scarcely deserves that description. The academies' interest was provoked by the plight of 13 scientists, who have been imprisoned since 1982 apparently for the nonviolent expression of their beliefs or because they were perceived by the government to be political threats. The academies have been asking, since 1983, for an official explanation of the alleged crimes, but have been favoured with only one response - a letter in 1983 from the attorney general of Somalia which dealt with only six of the thirteen cases, and which stated that those concerned were charged and found guilty of "offences against national unity and security and acts of violence", adding graciously that "none of them was sentenced to death".

The recent delegation's visit to Somalia seems to have been equally frustrating. The delegation was denied permission to visit the prisoners, and met only one government official, the minister of justice and religious affairs, who had little relevant information and little sympathy for the delegation's goals. Especially maddening was the inability to meet President Mohamed Siad Barre, who appears to have controlled every aspect of life in Somalia since he came to power in the military coup of 1969. Without official help, the delegation was obliged to rely on what it was told by prisoners' wives and other relatives, as well as relief agencies working in Somalia. Their stories were horrifying - prison cells so tiny that a prisoner could neither stand straight nor lie down, brutal torture to extract bogus confessions, routine arrests without trial or charges.

What crimes may have been committed? Two of the scientists, Dr Mohamed Aden Sheikh and Mr Mohamed Yusuf Weirah, were members of the former government (respectively the ministers of health and finance) while Aden was president of the Somali Academy of Sciences and Arts at the time of his arrest. Neither has been charged or tried since his arrest in 1982, although a trial date has now been arranged for 2 February. Others arrested were alleged to be "creating a subversive organization". The charges against others are even less explicit.

Somalia is one of the poorest countries in Africa. In biblical times it was known as the Land of Punt, and was the source for frankincense and myrrh. Today, with a population somewhere around 5.5 million, it is beholden to the international financial community for survival. It has little solid ground for hope, but appears bent on snuffing out what little there may be, its best prospects for the future. Next month's trial, when the cases of three others, as well as those of Aden and Weirah, will be heard, could be an opportunity to begin to make amends. The trail will be open, according to Somali officials, and anyone who wishes to attend may do so. Although the US academies' delegation expresses little hope that the trial will be any more than a rubber stamp of the prisoner's de facto guilt, it does provide an opportunity for civilized countries everywhere to express their outrage and chagrin at Somalia's actions. It is an opportunity none should pass up. 